\title{
Pine Flower Waste Innovation As A Plant Based Program Augmented Reality
}

\author{
Ayik Bela Saputra ${ }^{1 *}$, Imam Muhtarom $^{1}$, Ni’matul Rochmaniyah $^{2}$, Ardhana Iswari Citra Padmi ${ }^{2}$ \\ and Ika Rahmawati ${ }^{3}$ \\ ${ }^{1}$ Bachelor Program, Mechanical Engineering Department, Universitas Negeri Malang \\ ${ }^{2}$ Bachelor Program, Electrical Engineering Department, Universitas Negeri Malang \\ ${ }^{3}$ Bachelor Program, Accounting Department, Universitas Negeri Malang \\ *saputra.ayik22@gmail.com
}

\section{ABSTRACT}

Indonesia one of the tropical countries in the world can not be separated from environment problems like other developing countries. One of the causes of declining environment quality is the decline of forests in Indonesia. In 2009, Indonesia's forest area was by more than half, to about 88 million hectares. By the year 2013 the number is about 82 million hectares. One of the efforts to promote environment education is to familiarize planting plants to children from an early age from the school environment to the family environment. Therefore it is necessary an alternative in the form of planting media that can be used as a trigger tool of environmental care attitude and can feel the sensation of planting that educative by utilizing pine flower waste as an attractive and environmentally friendly planting medium. Besides as a planting medium is also intended as a instructional media especially elementary school students to high school students. This is because the planting medium has a goal to give an educative impression through information on plant species being planted and to increase awareness of the surrounding environment. If used as a medium of learning this planting media will bring up information about the plant being planted by way of scanning pot characters with gadgets then information about the classification of plants, root shapes, stems, leaves, flowers, how

Copyright @ $@ 2018 J$ Journal of Mechanical Engineering Science and Technology

All rights reserved

Keywords: planting media, environmental education, pine flower waste

\section{Introduction}

Indonesia's forests are generally dominated by various types of plants. One of the most supportive crops of this country's forests is pine trees. Pine type of merkusi is a versatile tree plant species because almost all parts of this plant can be utilized by human [6]. This matter is also in harmony with government focus which is promoting environmental education for the sake of world sustainability. According to Environmental education should be able to educate individuals, who are responsive to the rate of technological development, understand the problems in the biosphere, and productive, productive skills to maintain and sustain nature [1].

\section{Research method}

In the making of planting media or production process begins with research on environmental care, caring values and type of ornamental plant. Then do the character management of the plant type. The next stage of making outline of planting media as well as aligning and making pots, shown in Figure 1.

After the pot is completed and the augmented reality program will be testimony to the target of elementary school students up to college. The testimony aims to determine the level of success and how big the pot enthusiasts. After that it will be depicted in a graph and drawn a conclusion. 

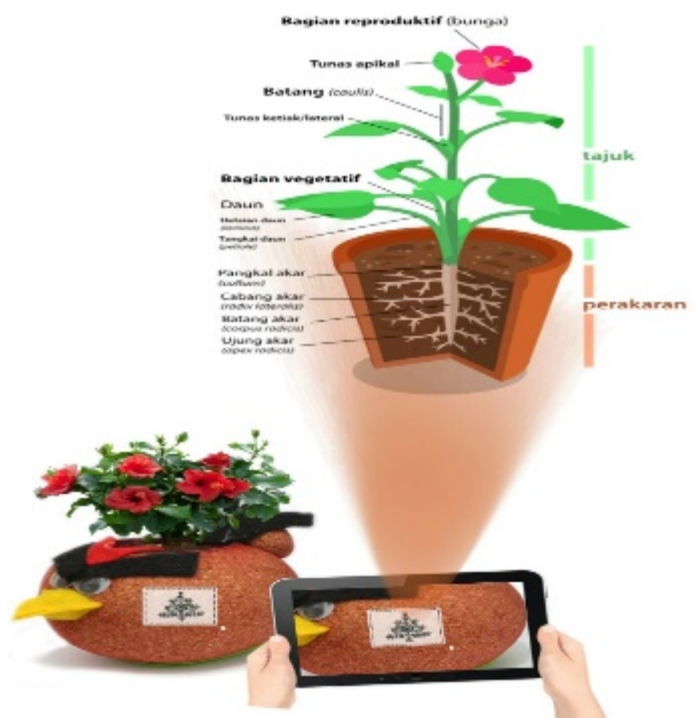

Fig. 1.Pot Shape and Augmented Reality Program

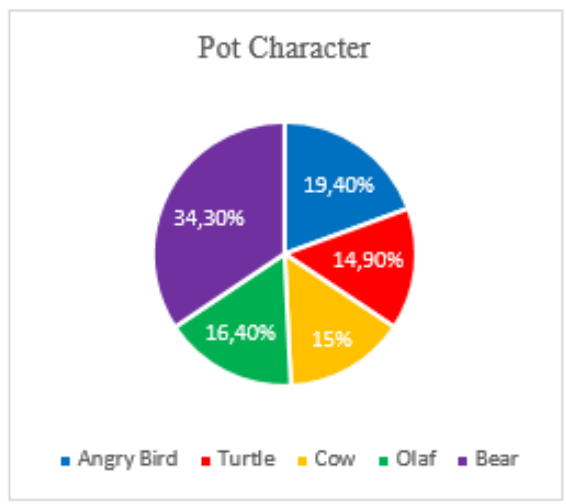

Fig. 2.Potential Character

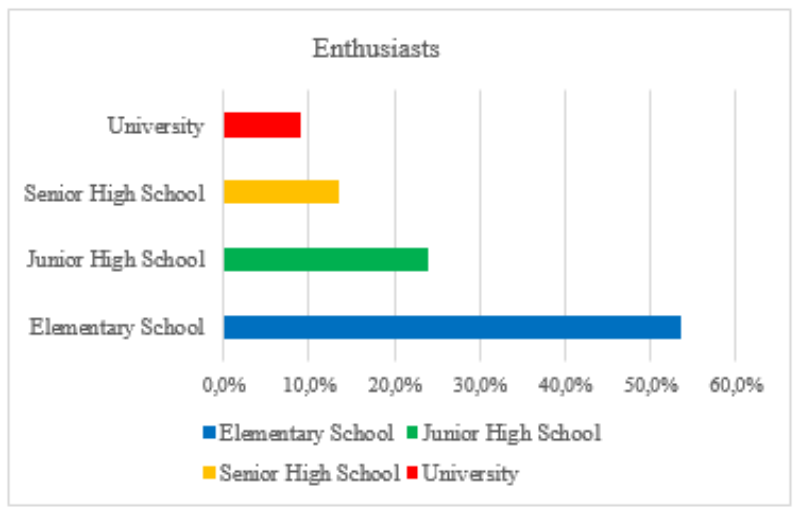

Fig. 3.Enthusiasts

\section{Results and discussion}

\section{A. Potential Character Pot}

Pot made 150 units with bear, angry bird, turtle, olaf, and cow. The most popular potted characters are bear-shaped pots as much as $34.3 \%$ while the least preferred is the shape of tortoise and cattle, which is $14.9 \%$. For more details can be seen in Figure 2. 


\section{B. Enthusiasts}

Meanwhile, when viewed from the most current enthusiasts is the number of elementary school students is a number of $53.7 \%$ and the lowest is from college enthusiasts, ie $9 \%$. If described in Figure 3.

Based on the Figure 2 and 3, graphs can be in the know that the shape of planting media in the form of pot many types of enthusiasts. Means for now media planting that aims to raise awareness of environmental education is still realized only for elementary school children whereas for higher need to be modified again form the character pot. Media learning is a technology used as a messenger to be used as the interests of the process learning [2]. While the media has always been an important element of instruction, in today's technology dominated society the paly an even more pivotal role in ID [4].

The use of real-life learning media that combined with matching cooperative learning is influenced [7]. People gathering information, distributing ideas and answering questions have begun to shift to electronic media, as evidenced by $85 \%$ of teenagers in 2008 [5]. This has led to the creation of innovative media literacy to address these issues. Learning media can be used well in both formal and non-formal conditions. The use of instructional media is for additional support of instruction and instruction in the class.

Every instructional media application should be unique in any case and be guided by both general learning principles and the context in which the media is used [3]. Learning media are usually deliberately designed to make the learning environment more interesting.

\section{Conclusion}

The shape of pot characters has an influence on pot enthusiasts, because the form is more childish so the demand is among the children so for the future need in the media planting more innovative again so that the demand to the level of adult so that environmental education can be realized. Although environmental education starts early but for the elderly need to be increase awareness about the importance of environmental education through planting media one of them. Real-shaped splitting media has greater attractiveness when compared with non-real-learning media forms.

\section{References}

[1] Barlia, Lily,Teori Pembelajaran Lingkungan Hidup Disekolah Dasar. Subang: Royyan Press, 2008 .

[2] Fikriyaturrohmah and Nurakiki, Pengembangan Media Pembelajaran Interaktif Hands-On Equation Berbantu Komputer Pada Materi Persamaan Linier Satu Variabel Untuk Siswa Kelas VII, 2010. [Online].

[3] Naz and Akbar, Use Of Media For Effective Instruction Its Importance : Some Consideration, "Journal Of Elementary Education",18 (1) 35-40, 2011.

[4] K. Richey and Tracey, The Instructional Design Knowledge Base Theory, Reserach And Practice, "Routledge Taylor And Francis Group New York And London", 2011.

[5] L. Young, Learning: Connection Traditional And Media Literacies In 21 St Century Learning, Journal Of Media Literacy Education, 4 (1) 70-81, 2012.

[6] A. Arel, Isolasi Senyawa Utama Kulit Batang Tumbuhan Pinus Dari Ekstrak Etil Asetat, "Jurnal Ilmiah Formasi", 12 (2) 27-35, 2016.

[7] Suwardi, The Effect Of The Use Of Real These Media In Cooperative Learning Type Group Investigation On The Ability Of Identifying Styles And Movement Students Of Class IV SDN II Pogalan Trenggalek, "Simki Pedagogia", 1 (1) 1-7, 2017. 